\title{
2019年度 日本付着生物学会 「イソギンチャク類の臨海勉強会」開催報告
}

日本付着生物学会は、2019年度の催事として「イソ ギンチャク類の臨海勉強会」の開催を下記の内容で開催 いたしました。

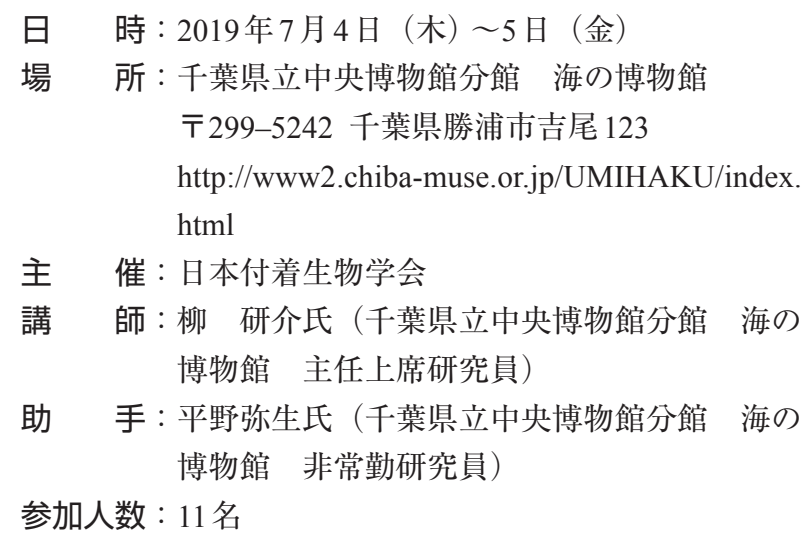

\section{企画の趣旨 :}

日本付着生物学会では、年一回の研究集会、シンポジ ウムなどに加えて、実際に対象生物に接してその分類や 扱い方を学ぶ機会を提供する勉強会を不定期（数年毎） に主催してまいりました。これまでに「ホヤの分類」、 「コケムシの分類」「フジッボの分類と生態」に関する勉 強会を開催してきました。その参加者や学会員からは、 このような勉強会をもっと開催してほしい、という要望 が数多く寄せられてきました。

今回はその中で特に「イソギンチャク類」について勉 強したいという要望が多かったこともあり、現在我が国 で精力的にイソギンチャク類の分類と生態について研究 を進めておられる柳 研介博士に講師をお願いし、博士 の勤務先でもあり、多様なイソギンチャクの観察に適し ている千葉県立中央博物館分館海の博物館とその周辺の フィールドにおいて「イソギンチャク類の臨海勉強会」 を開催することにしました。

\section{スケジュール（当日変更した内容を含む）}

\section{7月4日（木）}

$\begin{array}{ll}10: 00 & \text { 開会 } \\ 10: 00 \sim 10: 15 & \text { 概要説明 } \\ 10: 15 \sim 11: 40 & \text { イソギンチャク類に関する講義（分 } \\ & \text { 類・同定・観察方法等） } \\ 11: 40 \sim 12: 00 & \text { 事前採集試料の麻酔 } \\ 12: 00 \sim 13: 30 & \text { 昼食・昼食休憩時間帯に展示室自由見 } \\ & \text { 学 } \\ 13: 30 \sim 15: 00 & \text { 海の博物館バックヤード見学 } \\ 15: 00 〜 16: 00 & \text { 麻酔をかけた試料の固定作業 } \\ 16: 00 \sim ~ & \text { 宿 (扇屋) へ移動 } \\ 18: 00 〜 ~ & \text { 夕食・懇親会 }\end{array}$

7月5日（金）

$\begin{array}{ll}9: 30 & \text { 講義室集合・2日目開始 } \\ 9: 30 \sim 11: 20 & \text { 解剖・内部形態観察・刺胞のプレパ } \\ & \text { ラート作成観察 } \\ 11: 20 \sim 12: 20 & \text { 昼食 } \\ 12: 20 \sim 14: 00 & \text { 磯観察 (イソギンチャク類の生息場 } \\ & \text { 所・採集方法の説明等) } \\ 14: 00 \sim 14: 20 & \text { 後片付け・閉会 }\end{array}$

\section{勉強会の様子}

参加者 11 名の多くは、調査会社や環境コンサルタン 卜、研究所の職員がほとんどで、多くは普段の仕事で生 物の同定や分類などに関わっている方々でした。遠方よ りの参加者と勉強会運営役の植田は、参加者の宿泊先で ある民宿「扇屋」に前日から入りました。ここは、JR 鵜原駅から徒歩 4 分程度、海の分館までも徒歩約 15 分の 距離にあります。天気予報では、明日（7/4）は大荒れ とのことでした。

7月 4日（勉強会 1 日目）は果たして早朝より天候が 悪化し、豪雨・強風でした。そのため急遽スケジュール を入れ替え、当初予定していた午前中の磯観察と試料採 集は、翌日に順延することとしました。午前中は、柳博 士から、「イソギンチャクとは」、「イソギンチャクの分 類の現状」、「同定の仕方」、「観察方法等について」、講 義を受けました。

講義は詳細を究め、分類の用語や同定形質の用語はな れていないと難しいかと思われましたが、柳博士の丁寧 な説明と平易できれいなスライドのおかげで理解が進み ました（写真 1$) 。$ 柳博士は、イソギンチャクの現在の 分類上の問題点を指摘され、世界各国に保存されている タイプ標本のいくつかは同種と考えられるとのことでし た。直接海外に出向かれ世界各地で博物館のタイプ標本 を観察し、形態観察のみならず遺伝子的手法をも駆使し 精力的に研究されています。

その後、柳博士が事前に地先海岸より採集し飼養して いたイソギンチャク生体試料を各自 1 個体ずつ頂戴し、 麻酔を行いました。もともとは磯観察を行いそれぞれが 採取した試料を用いる予定でしたが、磯に出ることが出 来ないことから、貴重な飼養資料の提供をいただいた次 第です。

午後は、昼食後、海の博物館展示室の見学に続き、同 博物館のバックヤードのほぼ全体（1階・2階・3階）に ついて柳・平野両博士の引率の下、見学を行いました (写真2)。展示室は房総の海の特徴やそこに生息・来遊 する多様な生物の展示と解説があり、直接手で触れたり 音を聞いたりクイズを解いたり、大人から子供まで楽し める工夫が各所に凝らされていました。 


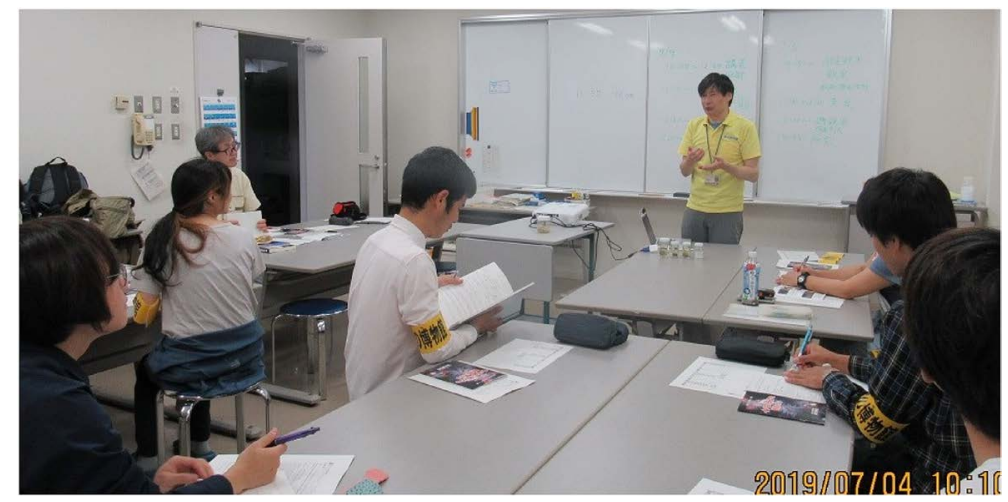

写真 1 柳博士による講義 イソギンチャクの新分類体系など

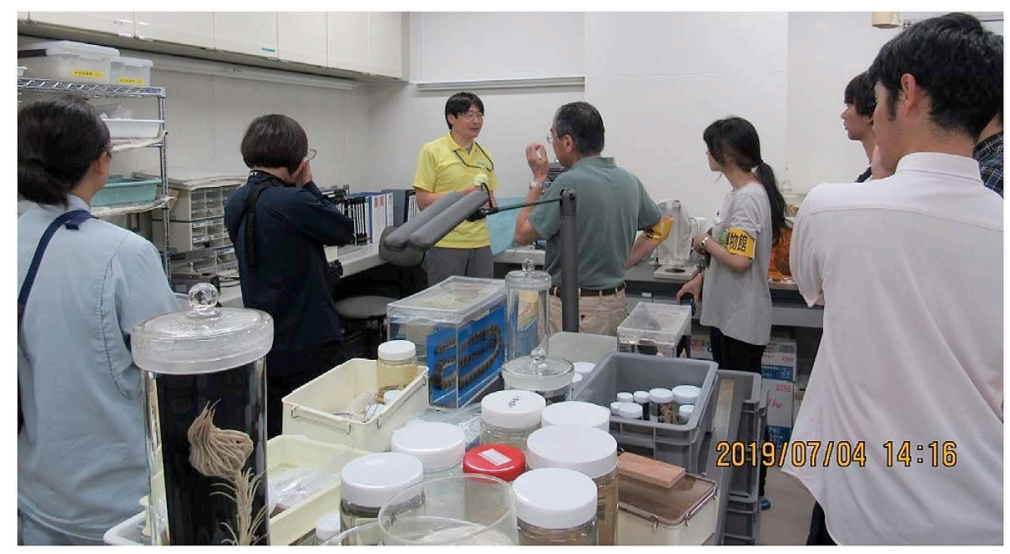

写真2 バックヤード見学

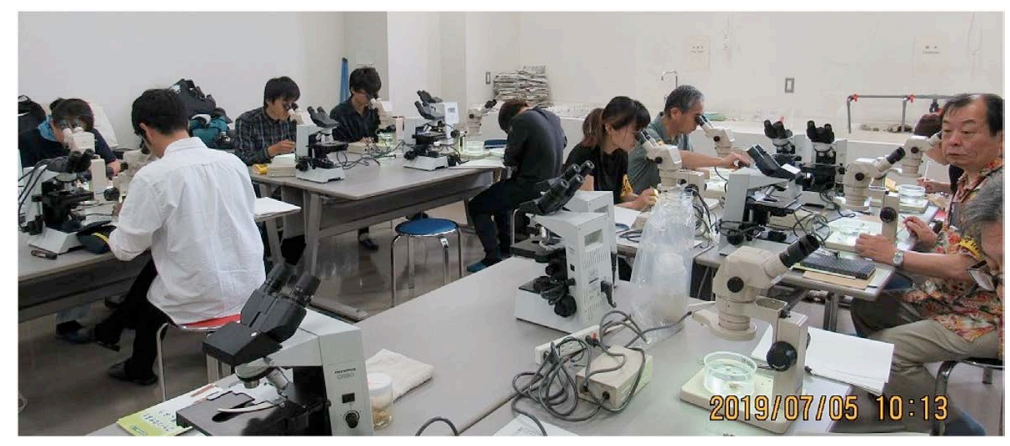

写真3 固定標本の顕微鏡観察

博物館のバックヤードは、貴重な標本の収蔵庫とそれ ぞれの専門研究員が標本類の分類や収蔵を行うために 必要な各種設備、その中には巨大なフォルマリンプー ル（大型標本固定用水槽）や地先の海水を引き込んで生 物を飼育する設備まで含まれていました。他には、我々 がお世話になった研修室や企画展示のデイスプレイを支 援する装置を収納・運用する部屋なども備えられていま す。

その後、麻酔をかけたイソギンチャク試料の固定作業 を行い、初日の勉強を終了しました。固定はフォルマリ ンで行いましたが、体腔を風船のように膨らませる必要 があり、シリンジを用いて固定溶液を吹き込むのです が、「私の方が出来が良い」とか「なかなか力ッコ良く
できない」とか皆楽しそうでした。

4 日の夜は、ご主人がマグロはえ縄漁師だという民宿 で地場の魚料理が満載の食卓を前にし、ごちそうに舌鼓 を打ちながらの懇親会となりました。柳博士も宿泊され たので、なぜ海の生物に興味を持ったか、研究上のご苦 労などなど、お酒も入り、先生や参加者それぞれの体験 談に、夜更けまで懇親は続きました。

7 月 5 日（勉強会 2 日目）は9時 30 分に講義室に集合後、 昨日固定した試料を参加者各自解剖し、イソギンチャク の内部の様子を横断面と縦断面から実体顕微鏡を用いて 観察しました (写真3)。その後体組織の一部を切り出し、 プレパラート試料化し、光学顕微鏡下で刺胞の観察や褐 虫藻の確認などを行いました。柳博士が白板に書かれた 


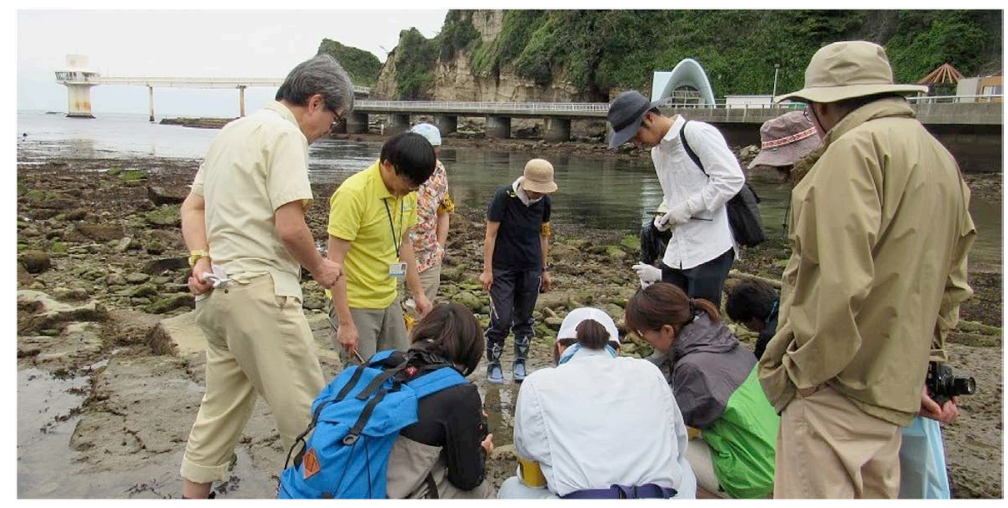

写真4 磯観察 6種のイソギンチャクを発見!?

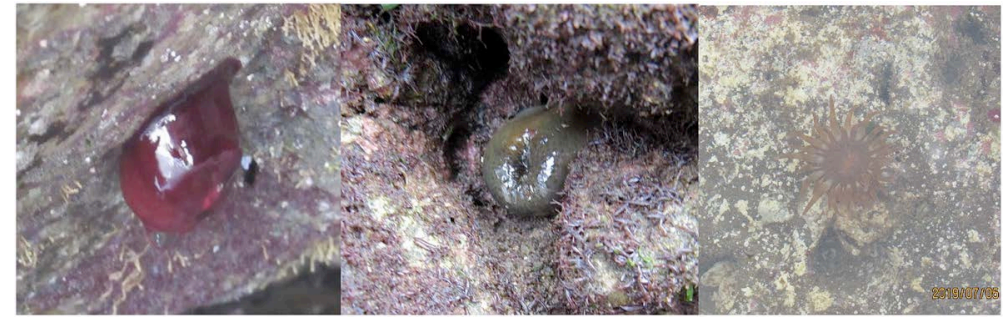

写真 5 ウメボシイソギンチャク、ベリルイイソギンチャク、ミナミウメボシイソギンチャク

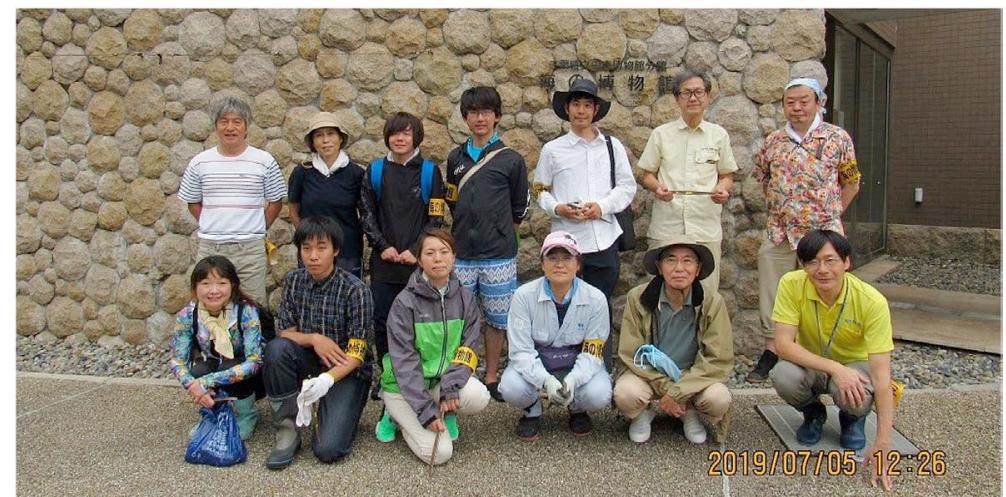

写真 6 集合写真

模式図と実物とを見比べ、助手の平野博士にお手伝いい ただいたりして作業を進めました。各自が作った標本を 見比べ合ったり、直接柳博士にも見ていただいたりしな がら、体の構造や分類形質の見分け方について十分に勉 強しました。この勉強会のハイライトとなる、最も充実 した時間だったと思います。

昼食後、前日からの雨はようやく止みました。この日 の干潮に合わせ 12 時 20 分頃から海の博物館前の磯浜に 出かけ、干出した平磯浜でのフィールド観察を行いまし た。観察内容は、「フィールド全体の様子」、「イソギン チャク各種の生息場所の説明」、「イソギンチャク各種の 探索」、「生息現場の観察」等でした（写真4）。

この観察で、ヨロイイソギンチャク、ベリルイイソギ
ンチャク、ウメボシイソギンチャク、ヒメイソギンチャ ク、タテジマイソギンチャク、ミナミウメボシイソギン チャクの6種が確認されました（写真 5)。その後講義室 に戻り、後片づけを行い、閉会の挨拶後に、2 日間の日 程をすべて終了しました。

学会の申し出を快諾下さり、終始懇切丁寧にわかりや すくご説明して下さった柳博士、控えめでありながら優 しく適切にご支援・ご指導下さった平野博士他、千葉県 立中央博物館分館海の博物館の関係各位に深く感謝申し 上げます。

(執筆) 日本付着生物学会 運営委員 企画担当 植田育男（加筆 原 猛也） 